Military Technical College

Kobry El-Kobbah,

Cairo, Egypt

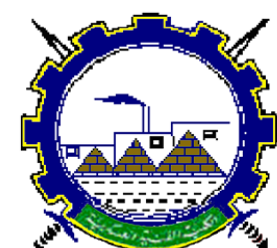

I.C.E.E.2016 $8^{\text {th }}$ International Conference

on

Chemical \& Environmental

Engineering

$19-21$ April 2016

\title{
CBP-2
}

\section{High Sensitive Analysis Method for Determination of Carbosulfan Pesticide in Bulk Form, in Soil and in Orange Matrix}

\author{
Mohamed M. Ghoneim ${ }^{1}$, Hanaa S. El-Desoky ${ }^{1}$, Fared M. El-badawy ${ }^{2 *}$ \\ ${ }^{1}$ Analytical and Electrochemistry Research Unit, Department of Chemistry, Faculty of \\ Science, Tanta University, 31527- Tanta, Egypt. \\ ${ }^{2}$ Egyptian ministry of industry Chemistry administration, Downtown, Cairo, Egypt. \\ * Corresponding author: E-mail address:unique_science@yahoo.com
}

\begin{abstract}
Stripping voltammetry method was applied for the sensitive determination of Carbosulfan. The best peak morphology of Carbosulfan was achieved in solution of $\mathrm{pH} 5.0$ which was chosen as a supporting electrolyte for the rest of the present analytical study. The achieved LOD of $6.0 \times 10^{-10} \mathrm{M}$ and LOQ of $2.0 \times 10^{-9} \mathrm{M}$ following the preconcentration of Carbosulfan by adsorptive accumulation onto the HMDE surface for $120 \mathrm{~s}$ at $-0.3 \mathrm{~V}$ confirmed the extreme sensitivity of the described SW-AdCSV procedure for assay of carbosulfan in bulk form. The proposed method was also validated via evaluation of linearity, repeatability, reproducibility, precision, accuracy, selectivity and robustness according to International Conference on Harmonization guidelines. Besides, the method was applied for determination of Carbosulfan in soil and in orange matrix. This method could be used in food quality control and agriculture laboratory.
\end{abstract}

Keywords: Carbosulfan, Pesticide, Determination, Stripping voltammetry.

\section{Introduction}

Carbosulfan2,3-Dihydro-2,2-dimethyl-7-benzfuranyl-N-[(dibutylamino)thio]-N-methylcarbamat is a brown viscose liquid with molecular mass 380.5 and boiling point 219.3, and degradation point 219.5, flash point 136.7 [1] Carbosulfan has a temporary acceptable daily intake (ADI) of $0-0.01 \mathrm{mg} \mathrm{kg}^{-1}$ bw and a maximum residue limit (MRL) of $0.05 \mathrm{mg} \mathrm{kg}^{-1}$ for the sum of carbosulfan, carbofuran and 3-hydroxy carbofuran in citrus fruits [2]. There are many methods for determination of carbosulfan depending on chromatography spectroscopy and fluorescence [2, 3-6]. 
Military Technical College

Kobry El-Kobbah,

Cairo, Egypt

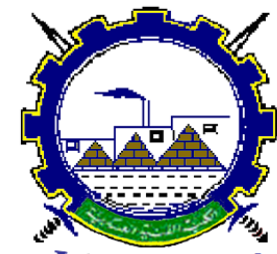

I.C.E.E.2016 $8^{\text {th }}$ International Conference

on

Chemical \& Environmental

Engineering

19 - 21 April 2016

The dropping mercury electrode (DME), hanging mercury drop electrode (HMDE) and thin mercury-film electrodes are usually used for determination of analytes that can undergo reduction where as solid electrodes such as glassy carbon, carbon paste, platinum and gold electrodes are used for measurements of analytes that can undergo oxidation. Adsorptive preconcentration of some compounds may also be accompanied by extraction into electrode pasting material [7].

Disadvantages of the use of mercury are its limited anodic range [8] (due to the oxidation of the mercury) and its toxicity [9]. However, compared to solid electrode materials, mercury is a very attractive choice of material because it has a high hydrogen overvoltage that greatly extends the cathodic potential window which enables us to determine wild range of materials with different electro active groups, and possesses a highly reproducible, readily renewable and smooth surface.

\section{Apparatus of voltammetric measurements}

A computer-controlled Potentiostat / Galvanostat (PAR) Model 273 (Princeton Applied Research, Oka Ridge, TN, USA) with software Model 270/250 was used. An electrode assembly (303A-PAR) incorporated with a three-electrode micro-electrolysis cell comprising of a hanging mercury drop electrode (HMDE) of area $0.026 \mathrm{~cm}^{2}$ as working electrode, an $\mathrm{Ag} / \mathrm{AgCl} / \mathrm{KCls}$ as reference electrode and a platinum wire as a counter electrode was used. A magnetic stirrer with a Teflon-coated magnet was used to provide the convective transport during the preconcentration step.

An Eppendorf centrifuge (Model 5417 C, Hamburg, Germany) was used for separation of precipitated proteins from human serum samples prior to the assay.

\section{Reagents and Solutions}

Britton-Robinson universal buffer ( $\mathrm{pH} 2-10)$, (Analytical grade) were prepared in deionized water and were used as supporting electrolytes. All the chemicals were of analytical sigma grade and were used without further purifications.

Standard stock solutions of 10-3 $\mathrm{M}$ were prepared by dissolving the equivalent of $3.8 \mathrm{mg}$ of carbosulfan in $10 \mathrm{~mL}$ (dimethylformamide) DMF and sonicated for one minute. For preparing lower levels standard solutions, $1 \mathrm{~mL}$ of stock solution of carbosulfan was mixed with DMF resulting in a final concentration of $10^{-4} \mathrm{M}$. Then $1 \mathrm{~mL}$ of the diluted drug solution was mixed with DMF by the same way to obtain concentration $10^{-5} \mathrm{M}$. All drug solutions were sonicated after dilution and stored at refrigerator.

\section{Preparation of drug product solutions}

Equivalent to $100 \mathrm{mg}$ of the drug was weighed of Zork ${ }^{\circledR}$ (carbosulfan 25\% EC) and transferred to a clean and dry measuring flask and then completed to 100 using DMF. One 
Military Technical College

Kobry El-Kobbah,

Cairo, Egypt

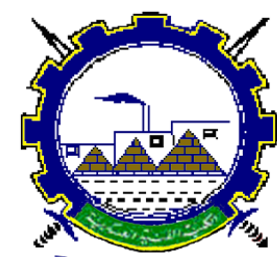

I.C.E.E.2016 $8^{\text {th }}$ International Conference

on

Chemical \& Environmental

Engineering

$19-21$ April 2016

milliliter of this was quantitatively transferred to $20 \mathrm{ml}$ volumetric flask and volume was completed with DMF. This solution was further diluted to get $10^{-4}$ and $10^{-5} \mathrm{M}$ carbosulfan, these solutions were analyzed by the proposed method.

\section{Orange and Soil matrix preparation}

Carbosulfan was extracted from $50 \mathrm{~g}$ of Orange peel mixed with $50 \mathrm{~mL}$ of orange juice or 100 grams of the soil by chloroform by refluxing for 1 hour in water bath, The organic solvent was evaporated on water bath then the residue was dissolved in DMF by sonication and then transferred to $10 \mathrm{ml}$ measuring flask completed to the mark using DMF after spiking it with different concentration of carbosulfan. Chloroform was used because it is hydrophobic organic solvent which can dissolve carbosulfan easily with low boiling point $(61.15 \mathrm{C} 0)$ so it is able to be evaporated easily.

\section{Electrochemical cell}

Unless otherwise mentioned, $10 \mathrm{ml}$ volume $(3 \mathrm{ml}$ of deionized water, $2 \mathrm{ml}$ of ethanol absolute and $5 \mathrm{ml}$ of B-R universal buffer) was used as the supporting electrolyte for Carbosulfan determination. Nitrogen was purged for $70 \mathrm{~s}$ to get rid of soluble oxygen. After that the SW voltammogrames were recorded from -0.3 to $-1.7 \mathrm{~V}$ just after adding the drug and $5 \mathrm{~s}$ quiet time and mentioned preconcentration time with stirring while applying preconcentration potential, and finally the peak current $\left(i_{p}\right)$ was measured.

\section{Results and discussion}

The adsorptive nature of Carbosulfan at the HMDE surface was investigated by recording the cyclic voltammogrames of $2 \times 10^{-6} \mathrm{M}$ carbosulfan at scan rate $400 \mathrm{mV} \mathrm{s}^{-1}$ in the B-R universal buffer of $\mathrm{pH} 5$ under open circuit condition without any accumulation (Figure 1, curve a) and following its preconcentration at accumulation potential $\left(\mathrm{E}_{\mathrm{acc}}\right)$ of $-0.3 \mathrm{~V}$ (vs. $\mathrm{Ag} / \mathrm{AgCl} / \mathrm{KCl}_{\mathrm{s}}$ ) for accumulation time $\left(\mathrm{t}_{\mathrm{acc}}\right)$ of $20 \mathrm{~s}$ (Figure $1,1^{\text {st }}$ cycle $\mathrm{b}$ ) and then the repetition of the cycle (Figure $1,2^{\text {nd }}$ cycle $\mathrm{c}$ ). It was observed that the cathodic peak current was remarkably increased after accumulation of the drug at electrode surface $\left(1^{\text {st }}\right.$ cycle, curve b) compared to that at open-circuit condition (without preconcentration; curve a). These results indicate the adsorption of carbosulfan onto surface of the HMDE.

Also, good linear relationships between $\left(i_{p}\right)$ and $(v)$ were obtained indicating that the reduction process of carbosulfan at the used electrode was controlled by adsorption rather than diffusion $[10,11]$.

Moreover, slope value of $\left(0.99 /\left(\mu \mathrm{AmV}^{-1} \mathrm{~s}\right)\right)$ of linear relationships between $\log i_{\mathrm{p}}$ and $\log v$ at $\mathrm{pH} 5.0$ (Figure 2) is very close to the theoretically expected value of (1.0) [11] for the electrode reaction of surface-confined species. 
Military Technical College

Kobry El-Kobbah,

Cairo, Egypt

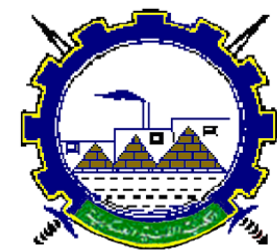

I.C.E.E.2016 $8^{\text {th }}$ International Conference

on

Chemical \& Environmental

Engineering

$19-21$ April 2016

\section{Electroanalytical studies}

Based on the adsorption behavior of Carbosulfan onto the mercury electrode surface, stripping voltammetric methods were optimized for its trace determination using different potential-waveforms. The optimum operational conditions for analytical determination of Carbosulfan using square-wave adsorptive cathodic stripping voltammetry (SW-AdCSV) were identified by studying the effect of $\mathrm{pH}$ of the medium, preconcentration parameters (potential $\mathrm{E}_{\mathrm{acc}}$ and time $\mathrm{t}_{\mathrm{acc}}$ ) and instrumental parameters \{ pulse- height $a$, scan increment $\Delta E_{s}$ and frequency $f\}$ on the voltammetric peak current magnitude.

\section{Effect of pH of the medium}

The compound under investigation is decomposed in water so kinetic study was carried out in media with different $\mathrm{pH}$ values to choose the suitable media for its analysis. Voltammogrames of $2 \times 10^{-6} \mathrm{M}$ for carbosulfan was recorded with instrumental parameters ( $f=60 \mathrm{~Hz}, a=25$ $\mathrm{mV}$ and $\Delta E s=10 \mathrm{mV}$ ) after preconcentration the analyte onto HMDE for $20 \mathrm{~s}$ under accumulation potential $\mathrm{E}_{\mathrm{acc}}=-0.3 \mathrm{~V}$. After adding carbosulfan to the analysis cell and then every 5 minutes we recorded the voltammograms as shown in (Figure 3 ). It was found that at every $\mathrm{pH}$, the signal decreased with time referring to the decomposition of the compound. Also, it was remarkable that the degradation was with higher rate in acidic medium but the decomposition rate at $\mathrm{pH}(5,6$ and 7$)$ was found to be mainly the same. However, (ip) at $\mathrm{t}=$ 0 s is higher in acidic medium (i.e., at $\mathrm{pH} 5$, the current is much higher than that at $\mathrm{pH} 6$ and 7). So $\mathrm{pH}=5$ was chosen as a supporting electrolyte for the rest of the present analytical study because of low degradation rate and high current.

\section{Effect of instrumental parameters}

Effect of pulse-parameters (frequency $\mathrm{f}=10$ to $120 \mathrm{~Hz}$, scan increment $\Delta \mathrm{Es}=2$ to $16 \mathrm{mV}$ and pulse -height $\mathrm{a}=5$ to $30 \mathrm{mV}$ ) on the peak current responses attempted by SW-AdCSV. Optimal f of $120 \mathrm{~Hz}, \Delta$ Es of $10 \mathrm{mV}$, and pulse height a of $25 \mathrm{mV}$ was chosen for the rest of the study.

\section{Effect of preconcentration conditions}

A better developed peak current was achieved at $\mathrm{E}_{\mathrm{acc}}=-0.3 \mathrm{~V}$. This is because of an increase of the accumulation rate, due to the more favorable alignment of the molecules by the electric field at the electrode solution interface $[12,13]$.

On the other hand, the dependence of SW-AdCSV peak current magnitudes of $5 \times 10^{-7} \mathrm{M}$ Carbosulfan, on the preconcentration time $\left(\mathrm{t}_{\mathrm{acc}}\right)$ of the analyte at $\mathrm{E}_{\mathrm{acc}}=-0.3 \mathrm{~V}$ was studied (figure 4). The response was linear up to $120 \mathrm{~s}$ indicating that the adsorptive equilibrium onto the mercury electrode surface was achieved [14]. So, preconcentration time of $120 \mathrm{~s}$ was applied in the application measurements. 
Military Technical College

Kobry El-Kobbah,

Cairo, Egypt

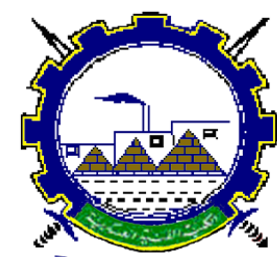

I.C.E.E.2016 $8^{\text {th }}$ International Conference

on

Chemical \& Environmental

Engineering

$19-21$ April 2016

The influence of the rest time was also considered and a time period of $5 \mathrm{~s}$ was chosen. On the other hand, square-wave signal were found to increase as the area of the HMDE was increased $\left(0.01\right.$ to $\left.0.026 \mathrm{~cm}^{2}\right)$; therefore, the present study was carried out at a HMDE area of $0.026 \mathrm{~cm}^{2}$.

Accordingly, the optimal conditions of the described SW-AdCSV methods were: scan rate and pulse-parameters of: $f=120 \mathrm{~Hz}, \Delta E s=10 \mathrm{mV}$ and $a=25 \mathrm{mV}$. Besides, the optimal preconcentration conditions were: $\mathrm{E}_{\mathrm{acc}}=-0.3 \mathrm{~V}$ (versus $\mathrm{Ag} / \mathrm{AgCl} / \mathrm{KCls}$ ) and $\mathrm{t}_{\mathrm{acc}}=120 \mathrm{~s}$ using the B-R universal buffer of $\mathrm{pH} 5$ as a supporting electrolyte.

\section{Validation of the analytical method}

Validation of an analytical method is the process by which it is established, by laboratory studies, that the performance characteristics of the method meet the requirements for the intended analytical applications. The elements required for method validation are: linearity range, limits of detection and quantitation, accuracy, precision, selectivity, robustness and intermediate precision $[15,16]$.

\section{Linearity}

Using the optimal conditions of the described SW-AdCS voltammetric procedure, linear relations between peak current and carbosulfan concentration over the range $(5-500 \mathrm{nM})$ obtained (figure 5). A good linearity is evident from values of the correlation coefficient $(\mathrm{r}=$ 0.995) and also standard error which confirms the validity of the SWAdCS procedure for determination of carbosulfan (Table 1).

\section{Limits of detection and quantitation}

Limits of detection (LOD) and quantitation (LOQ) of carbosulfan were calculated using the expression: $\mathrm{k} \times$ S.D./b [15], where $\mathrm{k}=3$ for LOD and 10 for LOQ, S.D. is the standard deviation of intercept (or blank) and $b$ is the slope of the calibration curve. The achieved LOD of $6.0 \times 10^{-10} \mathrm{M}$ and LOQ of $2.0 \times 10^{-9} \mathrm{M}$ following its preconcentration onto the HMDE by adsorptive accumulation for $120 \mathrm{~s}$ (Table 1) confirmed the sensitivity and validity of the described SW-AdCS voltammetric procedure for assay of carbosulfan.

\section{Precision}

Precision and accuracy [16] of the described SW-AdCSV method were evaluated by performing five replicate measurements for various concentrations of bulk carbosulfan over one day and for 3 days. The results obtained by the described methods are summarized in (Table 2). Non-significant differences were observed between the amounts of carbosulfan taken and found. Satisfactory mean recoveries $(\% \mathrm{R})$, relative standard deviations (\%RSD) 
Military Technical College

Kobry El-Kobbah,

Cairo, Egypt

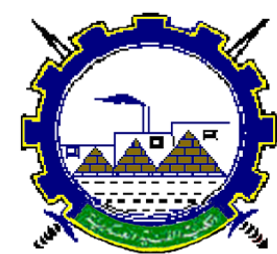

I.C.E.E.2016 $8^{\text {th }}$ International Conference

on

Chemical \& Environmental

Engineering

$19-21$ April 2016

and accuracy (Bais\%) were achieved indicating the repeatability, reproducibility, precision and accuracy of the described method for assay of carbosulfan.

\section{Robustness}

The robustness [16] of the measurements by means of the described SW-AdCS voltammetric procedure to assay of carbosulfan was examined by studying the effect of small variation of some important procedural conditions $(\mathrm{pH} 5 \pm 0.3)$, accumulation time $(\mathrm{t}=120 \pm 5 \mathrm{~s})$ and accumulation potential $\left(\mathrm{E}_{\mathrm{acc}}=-0.30 \pm 0.05 \mathrm{~V}\right)$. As shown in (Table 3), the achieved recoveries were reliable and thus the procedure could be considered robust.

\section{Application}

Using the described method, Carbosulfan was determined in orange and soil matrixes spiked with various concentration of the investigated pesticide. Linear relationships were achieved (figure 6,7 ) for soil and orange respectively, also was determined in the commercial formed of Zork ${ }^{\circledR}$ (carbosulfan $25 \%$ EC) with recovery $(98.5 \pm 1.2 \%)$.

Characteristics of the calibration curves of the developed SW-AdCSV method are shown in (Table 4). LOQ values of $\left(5.0 \times 10^{-9} \mathrm{M}\right.$ and $\left.5.5 \times 10^{-9} \mathrm{M}\right)$ and LOD values of $\left(1.5 \times 10^{-9} \mathrm{M}\right.$, $\left.1.65 \times 10^{-9} \mathrm{M}\right)$ for soil and orange were achieved, respectively.

\section{Conclusion}

Based on the reduction of adsorbed carbosulfan at the HMDE surface, simple and highly sensitive square wave adsorptive anodic stripping voltammetric method was developed for determination of carbosulfan in bulk form, orange and soil samples. The method was validated and was found to be efficient for the determination pesticide under investigation. This method was simple, sensitive, selective and precise for determination of the Carbosulfan and it could be used in food quality control and agriculture laboratory.

\section{References}

[1] UNEP/FAO. Rotterdam convention on the prior informed consent procedure for certain hazardous chemicals and pesticides in international trade. (2015) 110-120

[2] C. Soler, J. Manes, and Y. Pico, Determination of carbosulfan and its metabolites in oranges by liquid chromatography ion-trap triple-stage mass spectrometry. Journal of Chromatography A. 1109 (2006) 228-241.

[3] B. C. Leppert, J. C. Markle, R. C. Helt, and G. H. Fujie, Determination of carbosulfan and carbofuran residues in plants, soil, and water by gas chromatography. Journal of agricultural and food chemistry. 31 (1983) 220-223. 
Military Technical College

Kobry El-Kobbah,

Cairo, Egypt

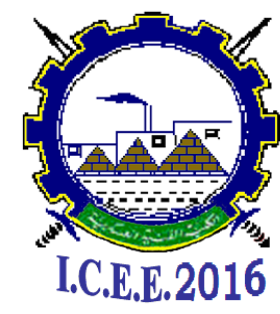

$8^{\text {th }}$ International Conference

on

Chemical \& Environmental

Engineering

$19-21$ April 2016

[4] M.W. Brooks and A. Barros, Determination of carbosulfan in oranges by highperformance liquid chromatography with post-column fluorescence. Analyst. 120 (1995) 2479-2481.

[5] A. Sao, A. K. Pillai, and V.K. Gupta, Spectrophotometric determination of carbosulfan in environmental samples. J. Sci. Ind. Res. 67 (2008) 1088-1091.

[6] C. Soler, B Hamilton, A Furey, K J. James, J Manes, and Y Pico, Liquid chromatography quadrupole time-of-flight mass spectrometry analysis of carbosulfan, carbofuran, 3-hydroxycarbofuran, and other metabolites in food. Analytical Chemistry. 79 (2007) 1492-1501.

[7] J. Wang and B.A. Freiha, Preconcentration and differential pulse voltammetry of butylated hydroxyanisole at a carbon paste electrode. Analytica chimica acta. 154 (1983) 87-94.

[8] Kelly, R.S., Analytical Electrochemistry: The Basic Concepts. Journal of the Analytical Sciences Digital Library, 2009.

[9] Clarkson, Thomas., The toxicology of mercury. Critical reviews in clinical laboratory sciences, 1997. 34(4): p. 369-403.

[10] J. B. Allen and R.F. Larry, Electrochemical methods: fundamentals and applications. Department of Chemistry and Biochemistry University of Texas at Austin, John Wiley \& Sons, Inc, (2001) 156-176.

[11] E. Laviron, L. Roullier, and C. Degrand, A multilayer model for the study of space distributed redox modified electrodes: Part II. Theory and application of linear potential sweep voltammetry for a simple reaction. Journal of Electroanalytical Chemistry and Interfacial Electrochemistry. 112 ( 1980) 11-23.

[12] Y. Yardim, E. Keskina, A. Leventa, M. Ozsozb, Z. S, Z. Senturka, Voltammetric studies on the potent carcinogen, 7, 12-dimethylbenz [a] anthracene: Adsorptive stripping voltammetric determination in bulk aqueous forms and human urine samples and detection of DNA interaction on pencil graphite electrode. Talanta. 80 (2010) 1347 1355 .

[13] V.K. Gupta, R Jain, M. Antonijevic, H Khani, M. N. Siddiqui, A Dwivedi, R Mishra, S Agarwal, Assay of nimodipine-an anti hypertensive drug, in bulk form and pharmaceutical formulations by cathodic adsorptive stripping voltammetry. Int. J. Electrochem. Sci. 6 (2011) 37-51.

[14] R. Kalvoda, Adsorptive stripping voltammetry of electroactive organic compounds. Analytica chimica acta. 162 (1984) 197-205.

[15] J. N. Miller, Analyst, 116, 3 (1991).

[16] The USA Pharmacopeia, The National Formularly, Convention Inc., USP33-NF 28 (2010). 
Military Technical College

Kobry El-Kobbah,

Cairo, Egypt

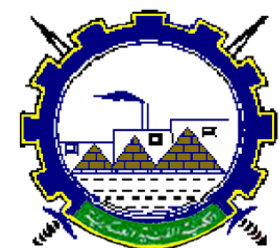

I.C.E.E.2016 $8^{\text {th }}$ International Conference

on

Chemical \& Environmental

Engineering

$19-21$ April 2016<smiles>CCCCN(C)C(=O)Oc1cccc2c1OC(C)(C)C2</smiles>

Scheme 1. Chemical structure of Carbosulfan

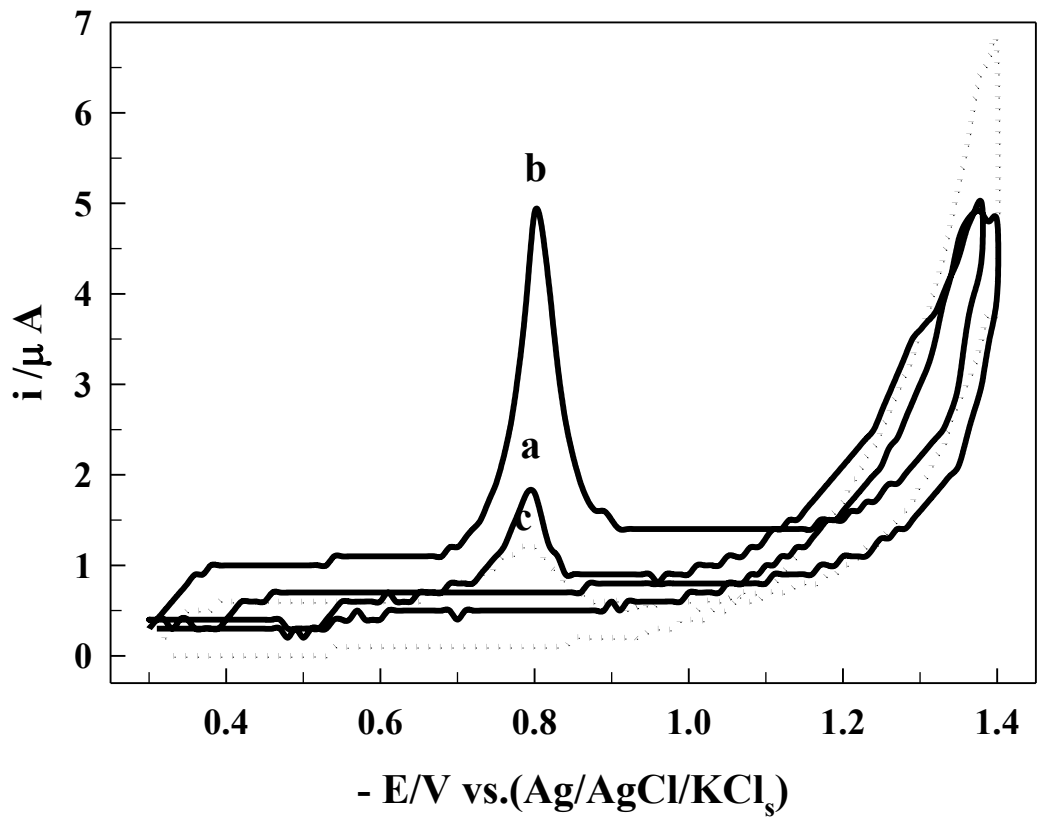

Figure 1: Cyclic voltammogrames of $2 \times 10^{-6} \mathrm{M}$ carbosulfan onto HMDE in B-R buffer $\mathrm{pH}=5$ : a) without preconcentration, b) with preconcentration at $-0.3 \mathrm{~V}$ at HMDE surface for $20 \mathrm{~s}$ and c) repetition cycle of (b). 
Military Technical College Kobry El-Kobbah, Cairo, Egypt

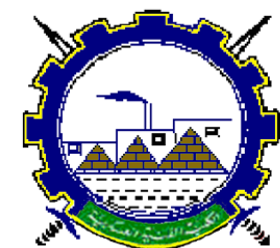

I.C.E.E.2016 $8^{\text {th }}$ International Conference on

Chemical \& Environmental Engineering

$19-21$ April 2016
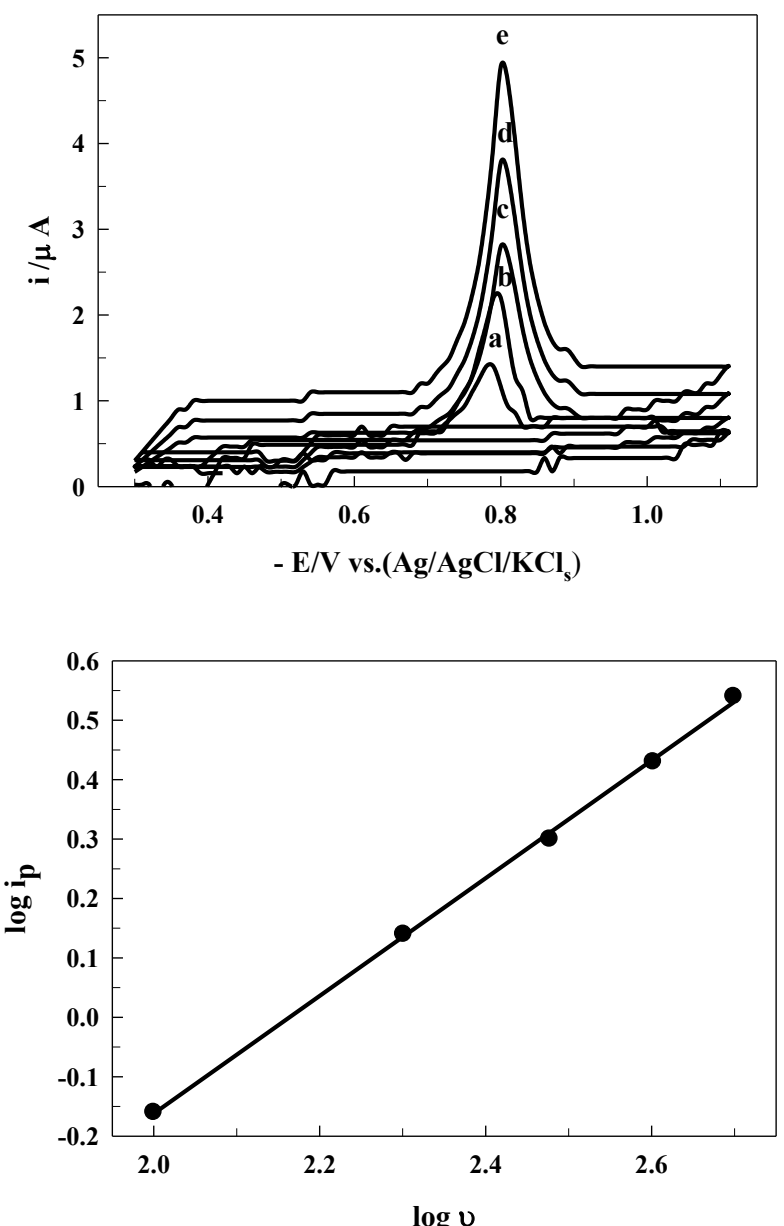

Figure 2: Cyclic voltammogrames of $2 \times 10^{-6} \mathrm{M}$ carbosulfan recorded in $\mathrm{B}-\mathrm{R}$ universal buffers of $\mathrm{pH}=5$ at HMDE at different scan rates: a) $v=100$, b) $v=200$, c) $v=300$, d) $v=$ 400 and $\mathrm{e}) \mathrm{U}=500 \mathrm{mV} \mathrm{s}-1\left(E_{a c c}=-0.3 \mathrm{~V}\right.$ and $\left.t_{a c c}=20 \mathrm{~s}\right)$ and its corresponding plot. 
Military Technical College Kobry El-Kobbah,

Cairo, Egypt

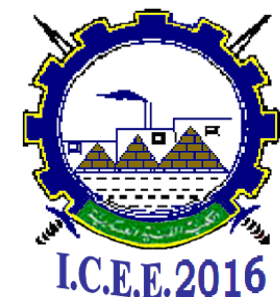

$8^{\text {th }}$ International Conference on

Chemical \& Environmental Engineering

$19-21$ April 2016
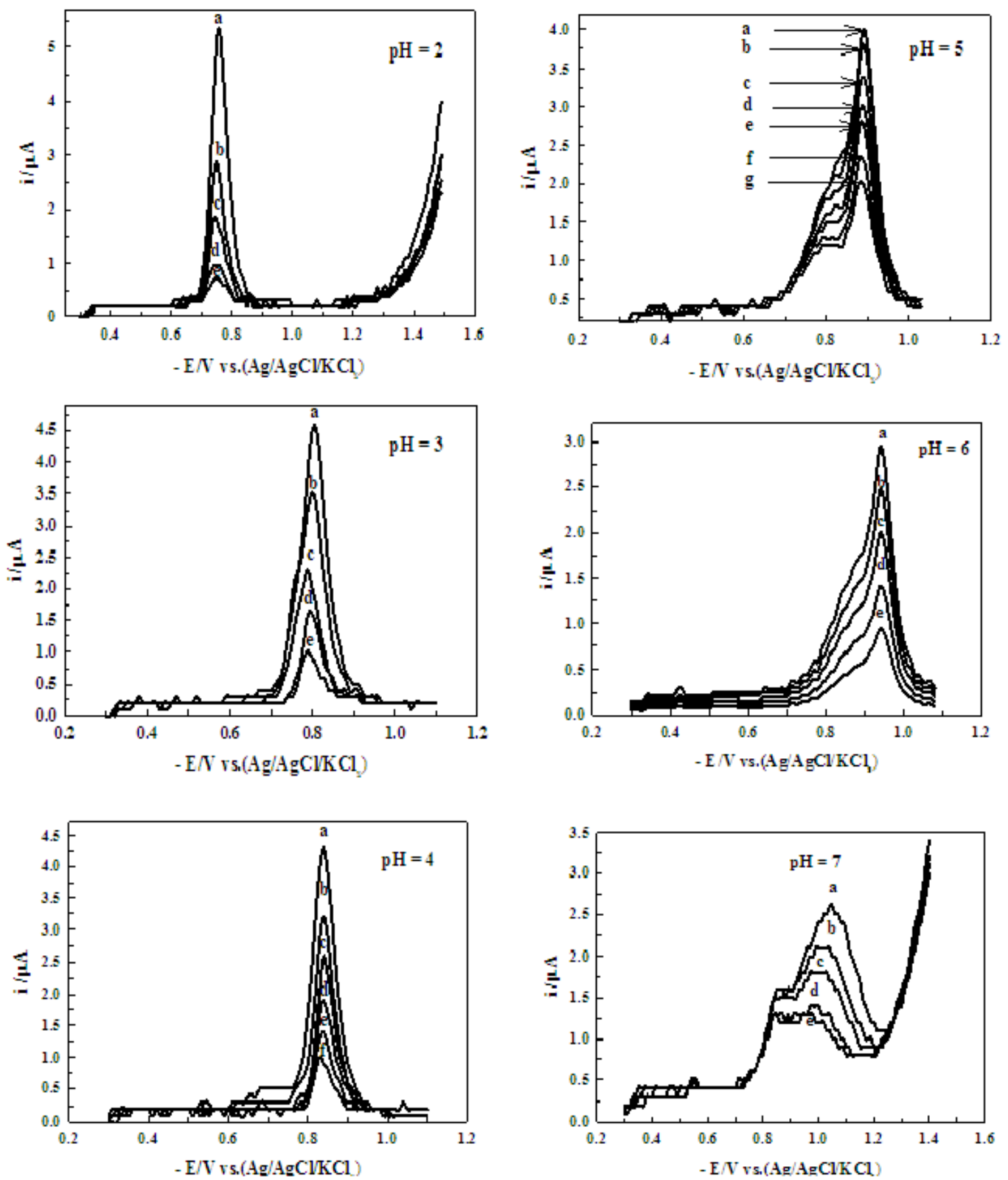

Figure 3: Voltammogrames for decomposition of $2 \times 10^{-6} \mathrm{M}$ carbosulfan onto HMDE in $B-R$ universal buffers of different $\mathrm{pH}$ values $\left(\mathrm{E}_{\mathrm{acc}}=-0.3 \mathrm{~V}, \mathrm{t}=20 \mathrm{~s}, f=60 \mathrm{~Hz}, \Delta E_{\mathrm{s}}=10\right.$ $\mathrm{mV}$, and $\Delta E_{a}=25 \mathrm{mV}$ ), while a) $\left.\mathrm{t}=0 \mathrm{~m}, \mathrm{~b}\right) \mathrm{t}=5 \mathrm{~m}, \mathrm{c}$ ) $\left.\left.\left.\mathrm{t}=10 \mathrm{~m}, \mathrm{~d}\right) \mathrm{t}=15 \mathrm{~m}, \mathrm{e}\right) \mathrm{t}=20 \mathrm{~m}, \mathrm{f}\right) \mathrm{t}=25$ $\mathbf{m}, \mathbf{g}) \mathbf{t}=\mathbf{3 0} \mathbf{m}$. 
Military Technical College Kobry El-Kobbah, Cairo, Egypt

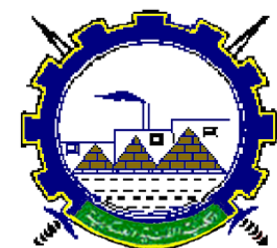

I.C.E.E.2016 $8^{\text {th }}$ International Conference

on

Chemical \& Environmental

Engineering

$19-21$ April 2016
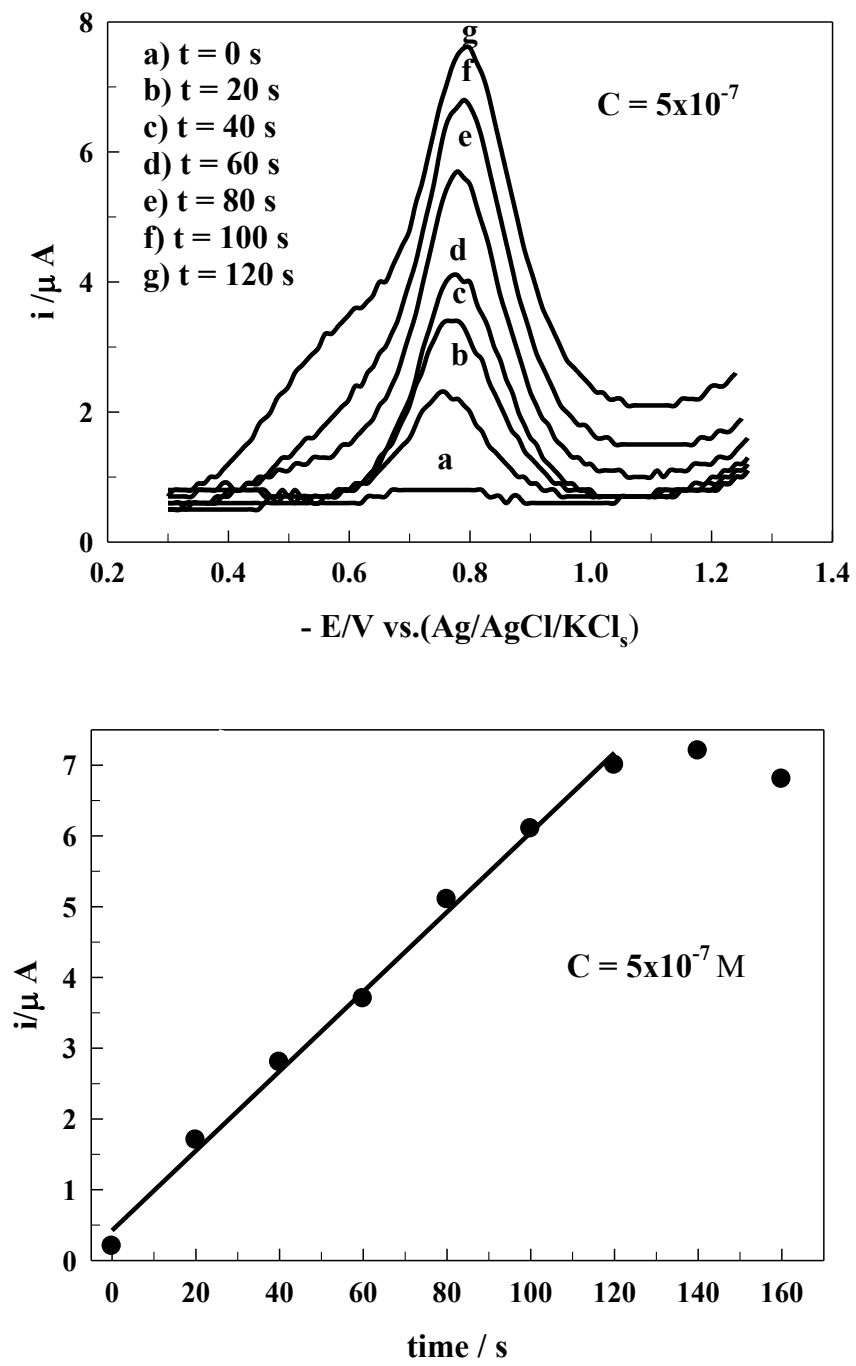

Figure 4: Effect of the preconcentration time $\left(t_{a c c}\right)$ on the SW-CdSV peak current $\left(i_{p}\right)$ of $5.0 \times 10^{-7} \mathrm{M}$ carbosulfanin B-R buffer of $\mathrm{pH} 5$ following preconcentration by adsorptive accumulation onto the HDME at $-0.3 \mathrm{~V} ; f=120 \mathrm{~Hz}, \Delta E_{s}=10 \mathrm{mV}$, and $E_{a}=25 \mathrm{mV}$. 
Military Technical College Kobry El-Kobbah, Cairo, Egypt

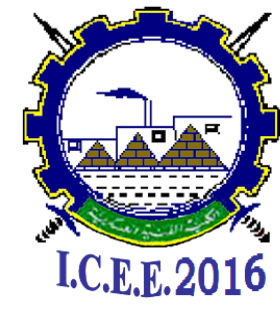

$8^{\text {th }}$ International Conference on

Chemical \& Environmental Engineering

$19-21$ April 2016
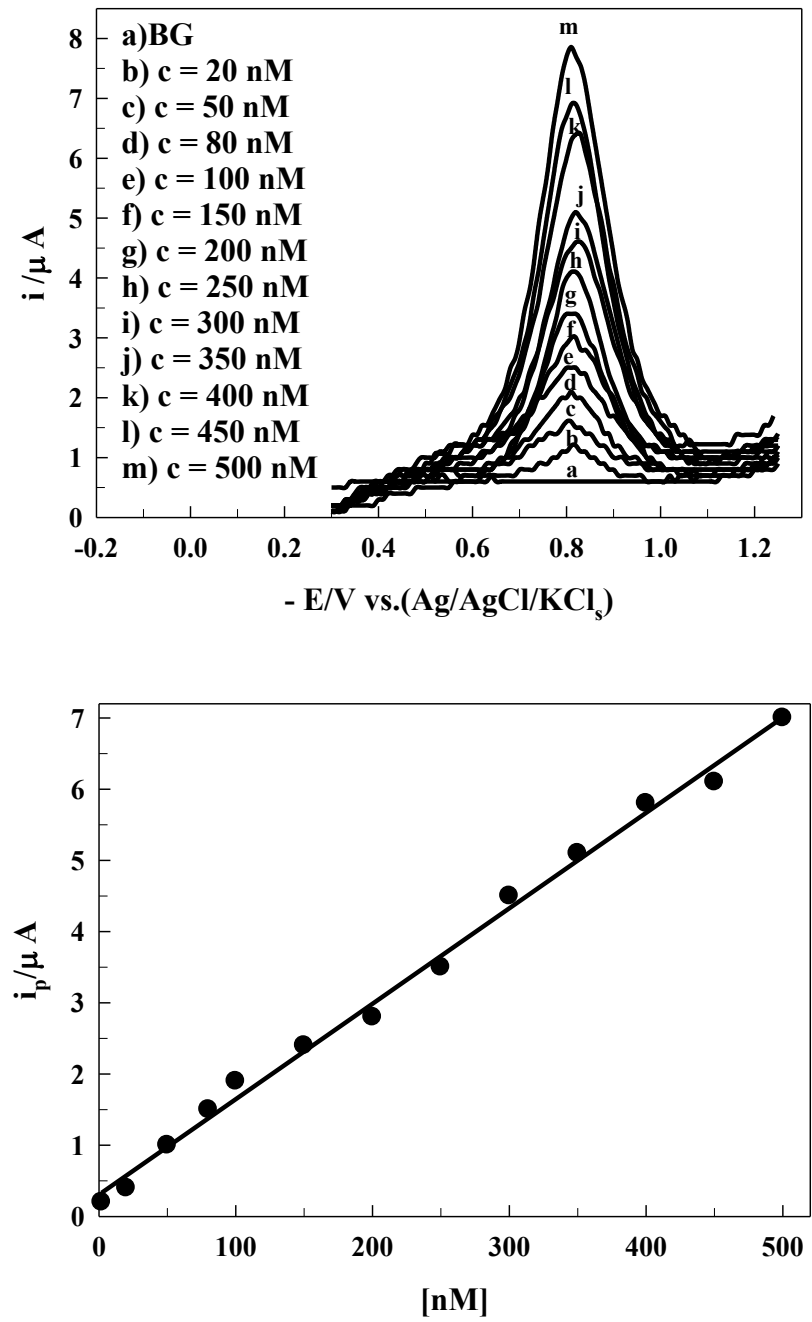

Figure 5: Representative SW-AdCAS voltammograms and its corresponding plot in the B-R universal buffer of $\mathrm{pH} 5$ for various concentrations of bulk carbosulfan at $\mathrm{HMDE}, \mathrm{E}_{\mathrm{acc}}=-0.3 \mathrm{~V}, \mathrm{t}_{\mathrm{acc}}=120 \mathrm{~s}$. 
Military Technical College

Kobry El-Kobbah,

Cairo, Egypt

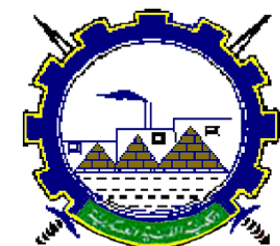

I.C.E.E.2016 $8^{\text {th }}$ International Conference

on

Chemical \& Environmental

Engineering

$19-21$ April 2016

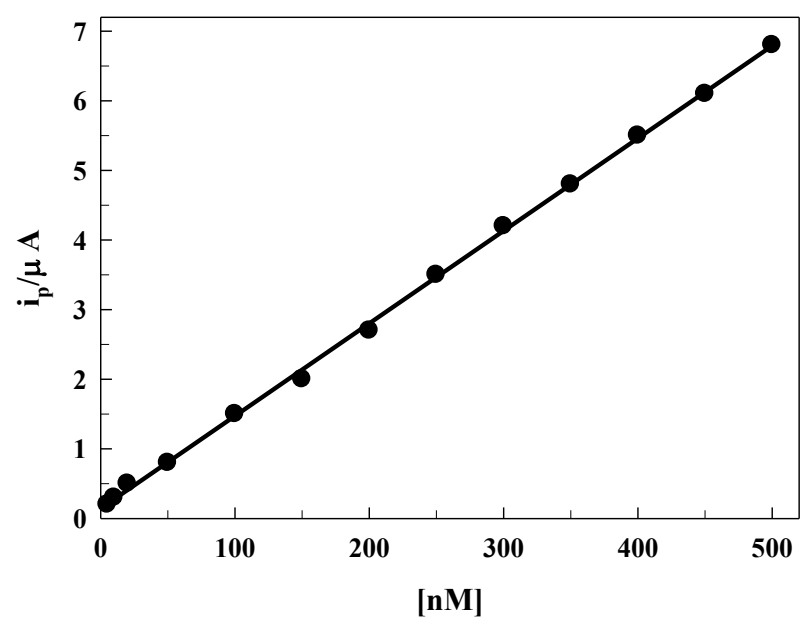

Figure 6: Representative SW-AdCS voltammograms and its corresponding plot in the B-R universal buffer of $\mathrm{pH} 5$ for various concentrations of carbosulfan spiked in soil matrix at $\mathrm{HMDE}, \mathrm{E}_{\mathrm{acc}}=-0.3 \mathrm{~V}, \mathrm{t}_{\mathrm{acc}}=120 \mathrm{~s}$.

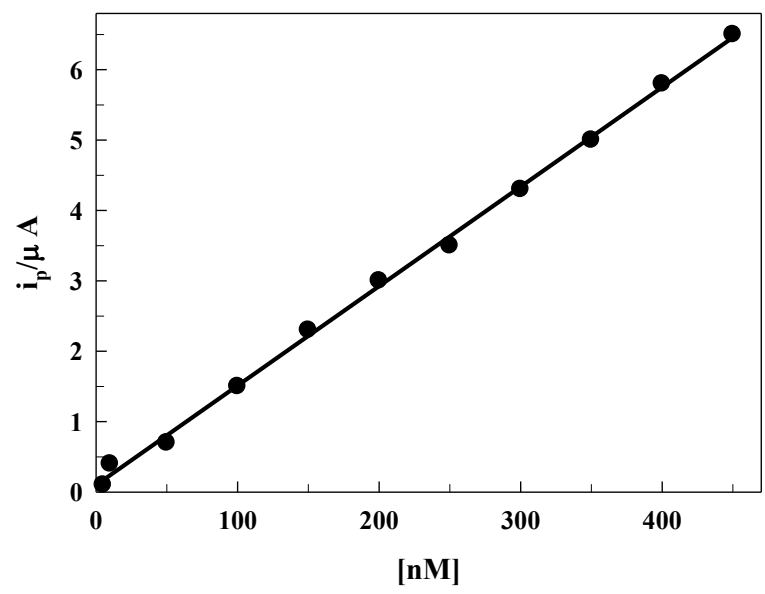

Figure 7: Representative SW-AdCSV plot in the B-R universal buffer of pH 5 for various concentrations of carbosulfan spiked in orange matrix at $\mathrm{HMDE}, \mathrm{E}_{\mathrm{acc}}=$ $-0.3 \mathrm{~V}, \mathrm{t}_{\mathrm{acc}}=120 \mathrm{~s}$. 
Military Technical College

Kobry El-Kobbah,

Cairo, Egypt

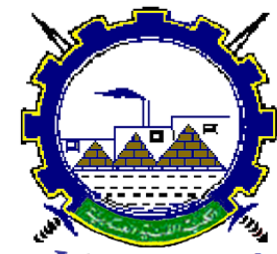

I.C.E.E. 2016 $8^{\text {th }}$ International Conference

on

Chemical \& Environmental

Engineering

$19-21$ April 2016

Table1: Characteristics of the calibration curve of SW-AdCSV determination of bulk carbosulfan in a B-R universal buffer of $\mathrm{pH} 5$; under the optimal operational conditions $(\mathrm{n}=5)$.

\begin{tabular}{|c|c|}
\hline Linearity range/ $\left(\mathrm{mol} \mathrm{L}^{-1}\right)$ & $5.0 \times 10^{-10}-3.5 \times 10^{-7}$ \\
\hline Slope $/(\mu \mathrm{A} / \mathrm{nM})$ & 0.0134 \\
\hline S.D & 0.005 \\
\hline S.E & $2.236 \times 10^{-3}$ \\
\hline Intercept $/(\mu \mathrm{A})$ & 0.304 \\
\hline S.D & 0.009 \\
\hline SE & $4.025 \times 10^{-3}$ \\
\hline Correlation coefficient $(r)$ & $0.997 \pm 0.002$ \\
\hline Mean $L O Q /(\mathrm{nM})$ & 2.000 \\
\hline Mean $L O D /(\mathrm{nM})$ & 0.667 \\
\hline
\end{tabular}

Table 2: Precision and accuracy of $1 \times 10^{-7} \mathrm{M}$ bulk carbosulfan by the optimized SW-AdCSV method using the HMDE $(\mathrm{n}=5)$.

\begin{tabular}{cccc}
\hline Day & $\begin{array}{c}\text { Recovery } \\
\% \mathrm{R}\end{array}$ & $\begin{array}{c}\text { Accuracy } \\
\% \text { Bias }\end{array}$ & $\begin{array}{c}\text { Precision } \\
\text { RSD \% }\end{array}$ \\
\hline \multirow{3}{*}{1} & 100.2 & 0.2 & 1 \\
& 99.88 & -0.12 & 0.95 \\
& 99.9 & -0.1 & 0.72 \\
\hline \multirow{3}{*}{2} & 100.5 & 0.5 & 1.01 \\
& 101.2 & 1.02 & 0.88 \\
& 100.1 & 0.1 & 0.78 \\
\hline \multirow{3}{*}{3} & 99.8 & -0.2 & 0.95 \\
& 100.42 & 0.42 & 0.92 \\
& 100.7 & 0.7 & 0.61 \\
\hline
\end{tabular}


Military Technical College

Kobry El-Kobbah,

Cairo, Egypt

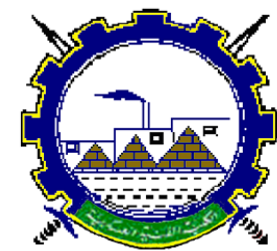

I.C.E.E.2016 $8^{\text {th }}$ International Conference

on

Chemical \& Environmental

Engineering

19 - 21 April 2016

Table 3: Validation studies for determination of $5 \times 10^{-8} \mathrm{M}$ bulk SORA by means of the described SW-AdCSV method at HMDE.

\begin{tabular}{ccc}
\hline Variables & $\begin{array}{c}\text { Operational } \\
\text { Conditions }\end{array}$ & $\begin{array}{c}\mathbf{R} \pm \mathbf{R S D} \% \\
(\mathbf{n}=\mathbf{3})\end{array}$ \\
\hline $\mathrm{pH}$ & $\mathrm{E}_{\mathrm{acc}}=-0.3 \mathrm{~V}$ & 101.150 \\
4.7 & $\mathrm{t}_{\mathrm{acc}}=120 \mathrm{~s}$ & 100.251 \\
5.0 & & 99.051 \\
5.3 & $\mathrm{pH}=5$, & \\
\hline Preconcentration potential & $\mathrm{t}_{\mathrm{acc}}=120 \mathrm{~s}$ & 99.276 \\
$\left(E_{a c c}\right)$ & & 100.510 \\
-0.25 & & 98.992 \\
-0.30 & & \\
-0.350 & $\mathrm{pH}=5$, & 98.529 \\
115 & $\mathrm{E}_{\mathrm{acc}}=-0.3 \mathrm{~V}$ & 100.321 \\
120 & & 101.115 \\
125 & & \\
\hline
\end{tabular}

Table 4: Characteristics of the calibration curves of SW-AdASV determination of spiked carbosulfan into soil and orange samples in a B-R universal buffer of $\mathrm{pH}$ 5; under the optimal operational conditions.

\begin{tabular}{|l|c|c|c|c|c|}
\hline \multicolumn{1}{|c|}{ matrix } & $\begin{array}{c}\text { Linearity range } \\
(\mathbf{M})\end{array}$ & $\begin{array}{c}\text { Regression equation } \\
\text { (r) }\end{array}$ & $\begin{array}{c}\text { LOQ } \\
(\mathbf{M})\end{array}$ & $\begin{array}{c}\text { LOD } \\
(\mathbf{M})\end{array}$ \\
\hline Soil & $5.0 \times 10^{-9}-5.0 \times 10^{-7}$ & $\begin{array}{c}\mathrm{i}_{\mathrm{p}}(\mu \mathrm{A})=(0.013 \pm 0.006) \mathrm{C}(\mathrm{n} \\
\mathrm{M})+(0.144 \pm 0.0065)\end{array}$ & $\frac{0.997}{0.997}$ & $\frac{5.0 \times 10^{-9}}{5.5 \times 10^{-9}}$ & $\frac{1.5 \times 10^{-9}}{1.65 \times 10^{-9}}$ \\
\hline -Orange & $\frac{5.5 \times 10^{-9}-4.5 \times 10^{-7}}{\mathrm{i}_{\mathrm{p}}(\mu \mathrm{A})=(0.014 \pm 0.005) \mathrm{C}(\mathrm{n}}$ & & & \\
\hline
\end{tabular}

